\title{
Development Strategy in Mangrove Tourism Area Exotic Mengare Gresik Regency East Java
}

\author{
Erlinda Indrayani ${ }^{1}$, Mukhammad Fatchul Alam ${ }^{2}$, Mochammad Fattah ${ }^{3}$ \\ \{erlinda_indrayani@ub.ac.id ${ }^{1}$ \} \\ Universitas Brawijaya, Indonesia ${ }^{1,2,3}$
}

\begin{abstract}
Mangrove Tourism Area Mengare is a new tourism area that was operated in mid-2017and this area has a wide range of attractions which oriented to nature features such as river, beaches, tropical forest vegetation, and mangrove. Besides the function as a tourism place, it also has an important role in the ecological function to withstand the abrasion. Due to their both functions, it must be maintained for the continuity of the region's function. Research aims of this research were to analyse, acknowledge and determine (1) The condition of mangrove tourism area Mengare with ECOS approach (2) value of Recreational Zone index on mangrove tourism Area Mengare and (3) Ecotourism development strategy. The research was held in March in 2019. This research was done by qualitative descriptive study with the sampling techniques, purposive sampling, and incidental sampling, with four data collection techniques i.e. interviews, observations, documentation, and questionnaire. The Data obtained was analyzed by the ECOS approach. The results of this research showed that the tourist area of Exotic Mengare Mangrove is in intermediate status. Where the tourism area is still oriented to nature and has done the addition of technology their in. So that the development strategy carried out has to set ecological functions and positively impact the socio-economic community around.
\end{abstract}

Keywords: Tourism, ECOS, Development.

\section{Introduction}

Based on the Regional Spatial Plan regarding the land use allotment in 2010-2030, only 82,851 meter of land is used for the tourism sector and also cultural based tourism [1]. However, Gresik government has started to develop and facilitate the development of the tourism sector in Gresik, both are modern tourism and related to nature tourism, for instance, Mengare is one of the areas within the Bungah, Gresik. In July 2017 the area was opened to the public as a tourist attraction by offering all the tourism spots around the river, beach, mangrove, tropical forests, fishing spot and historical spot.

The effort to maximize the potential in the Mengare, it is necessary to have a development strategy that will be applied, and it will make this region developed and more benefit to tourists, and the surrounding community. However, the management of this tourism has not been aligned with good tourism management, also it still lack of community interest, moreover, lack of services and facilities provided by management.

The research objectives of this research were:

a) The condition of mangrove tourism area Mengare with ECOS approach

b) Value of Recreational Zone index on mangrove tourism Area Mengare 


\section{c) Ecotourism development strategy}

\section{Research Method}

Data collection was carried out in this study through interviews, observation, documentation, and filling out the questionnaire. The target of observation in this study was the condition of facilities in the venue. The documentation in this study was carried out by collecting literature from libraries, as well as those from the internet. The questionnaire in this study was used to obtain information from visitors to the Mengare mangrove tourim area. Number of Samples has taken using Linear Time Function with incidental sampling technique as many as 24 Respondents, 3 exotic mengare staff, and 3 local communities.

In analyzing data using ECOS each independent variable will be analyzed and categorized in an existing category. Each component will be evaluated using spectrum according to Table 1.

Table 1. Table of variable valuation provisions (ECOS component)

\begin{tabular}{|c|c|c|c|c|c|}
\hline \multirow{2}{*}{ No } & \multirow{2}{*}{ Variabel } & \multirow{2}{*}{ Indicator } & \multicolumn{3}{|c|}{ Status } \\
\hline & & & Eco specialist & Intermediate & Eco generalist \\
\hline & Level & & 2 & 1 & 0 \\
\hline 1 & Access & $\begin{array}{l}\text { Difficulties, } \\
\text { Transportation, } \\
\text { targeted visitors } \\
\text { and Promotions }\end{array}$ & $\begin{array}{l}\text { Difficult to } \\
\text { reach, there are } \\
\text { no vehicles and } \\
\text { visitors are local } \\
\text { residents }\end{array}$ & $\begin{array}{l}\text { Can be reached } \\
\text { by light } \\
\text { vehicles }\end{array}$ & $\begin{array}{l}\text { mass vehicles } \\
\text { can be reached, } \\
\text { visitors from } \\
\text { various regions }\end{array}$ \\
\hline 2 & $\begin{array}{l}\text { Other related } \\
\text { resources }\end{array}$ & $\begin{array}{l}\text { Other activities } \\
\text { besides tourms }\end{array}$ & $\begin{array}{l}\text { Not realted to } \\
\text { active and } \\
\text { another tourist } \\
\text { attraction Natural }\end{array}$ & $\begin{array}{l}\text { Minimal } \\
\text { connection }\end{array}$ & Very related \\
\hline 3 & Attractions & $\begin{array}{l}\text { Naturalness of } \\
\text { attraction }\end{array}$ & Natural & $\begin{array}{l}\text { Slightly } \\
\text { influenced by } \\
\text { technology }\end{array}$ & $\begin{array}{l}\text { Very influenced } \\
\text { by technology }\end{array}$ \\
\hline & Infrastructure & $\begin{array}{l}\text { Facilities and } \\
\text { infrastructure, } \\
\text { the completeness } \\
\text { of the facilities, } \\
\text { the addition of } \\
\text { facilities }\end{array}$ & Less & Enough & More \\
\hline 5 & $\begin{array}{l}\text { Social } \\
\text { interactions }\end{array}$ & $\begin{array}{l}\text { Local population } \\
\text { interaction }\end{array}$ & There is no & Minimal & Big \\
\hline 6 & $\begin{array}{l}\text { Level of } \\
\text { ability and } \\
\text { knowledge }\end{array}$ & $\begin{array}{l}\text { Tourist } \\
\text { knowledge and } \\
\text { abilities }\end{array}$ & It is necessary & $\begin{array}{l}\text { Enough is } \\
\text { necessary }\end{array}$ & No need \\
\hline 7 & $\begin{array}{l}\text { Impact of } \\
\text { visitors }\end{array}$ & $\begin{array}{l}\text { Impact and } \\
\text { supervision }\end{array}$ & There is no & $\begin{array}{l}\text { Relatively } \\
\text { impactful }\end{array}$ & Very impactful \\
\hline
\end{tabular}


According to Wardhani [3], to calculate the characteristics of tourist attractions from the existing spectrum can be assessed by the formula:

$$
\begin{aligned}
& R Z I=\sum\left(\frac{N i}{N \max }\right) X 100 \% \\
& \text { RZI : Recreation Zone Index } \\
& \text { Ni : Value of Parameter-i }
\end{aligned}
$$

- $\quad$ N1 Access Components

- $\quad$ N2 Related Resource Components

- $\quad$ N3 Attraction Components

- $\quad$ N4 Infrastructure Components

- $\quad$ N5 Ability and knowledge Components

- $\quad$ N6 Social interaction Components

- $\quad$ N7 Visitor impact Components

$\mathrm{N}$ max : Maximum value entire categories

The results can be classified by looking at Table 2

Tabel 2. Score of Recreational Zone Index

\begin{tabular}{ccc}
\hline No & Index & Category \\
\hline 1 & $>67 \%$ & Eco Specialist (ES) \\
2 & $66 \%-34 \%$ & Intermediate (IM) \\
3 & $0 \%-33 \%$ & Eco Generalist (EG) \\
\hline
\end{tabular}

\section{Result and Discussion}

\subsection{Profile of Tourism Area}

Mangrove tourism in Mengare has the brand name "Exotic Mengare" began operating in July 2017. This tourist area basically has the main aspects of the beach and mangrove forests. This area has 17 species of mangroves and dominated by Avicenia and Rizhopora. The differentiator from tourist attractions that is in addition to the beach and mangrove in this area also presents historical tourism and also tropical forests. The concept of this tour was tourism that maintains the existing natural form as it is promote education related to estuary and mangrove ecosystems. The following is the number of tourist visits in 2018-2019.

\begin{tabular}{lll} 
& \multicolumn{2}{c}{ Table 3. Number of visitors } \\
\hline Years & Month & Number of Visitor \\
\hline 2018 & Januari & 2.201 \\
& Februari & 963 \\
& Maret & 797 \\
& April & 714 \\
& Mei & 567 \\
& Juni & 963 \\
& Juli & 1.174 \\
\hline
\end{tabular}




\begin{tabular}{lll}
\hline & Agustus & 544 \\
September & 680 \\
& Oktober & 459 \\
November & 412 \\
& Desember & 1.044 \\
& Januari & 431 \\
& Februari & 157 \\
& Maret & 151 \\
& April & 231 \\
& Mei & 59 \\
\hline
\end{tabular}

Source: The Mengare Exotic Work Team, 2019.

\subsection{Regional conditions based on the ECOS approach}

\subsubsection{Access Components}

Accessibility is one of the facilities that makes it easy for tourists to reach tourist destinations. Important factors in accessibility includes: travel plans, tourist attraction data, airports, land transportation, time needed, transportation costs, and the number of vehicles [4].

The exotic mengare mangrove tourism area is quite far from public transportation facilities, where the nearest airport to the location is Juanda Airport which is located in the city of Sidoarjo and is $66.7 \mathrm{Km}$ away. While for the nearest station is Sitting Station, which is 33.6 $\mathrm{Km}$ and for the nearest terminal is Bunder Terminal which is $26.3 \mathrm{Km}$.

Information related to attractions are offered by the manager. Tourists can access this information through social media (exoticmengare_official) owned by the manager. In this case social media is also used by managers to promote the Exotic Mengare mangrove tourism area to the general public.

Based on the results of the questionnaire that was obtained from respondents regarding access components obtained from 24 tourist respondents and also 3 managers and 3 people obtained results that can be seen in Table 4 .

Table 4. Ecos Assessment of Access Components

\begin{tabular}{lccccc}
\hline \multicolumn{2}{c}{ Subject Assessment } & ES & IM & EG & Total \\
\hline $\begin{array}{l}\text { Difficulty reaching tourist } \\
\text { attractions }\end{array}$ & 7 & 20 & 3 & 30 \\
$\begin{array}{l}\text { Transportation to reach the } \\
\text { region }\end{array}$ & 0 & 30 & 0 & 30 \\
$\begin{array}{l}\text { Visitor Target } \\
\text { Promotion }\end{array}$ & 11 & 19 & 0 & 30 \\
Total & 24 & 6 & 0 & 30 \\
\hline Indicator & 42 & 75 & 3 & \\
\hline
\end{tabular}

The access component in the tourist area was classified as Inttermediate, which is seen from several characteristics namely difficulty of access, transportation, target visitors and promotion. 


\section{a. Difficulty reaching tourist attractions}

According to [5] one factor supports the development of attractions. Good quality roads and the availability of public transportation will help tourists easily find the location of attractions.however, tourist experienced with narrow and broken road conditions, and also the lighting available was also minimal.In addition there is also no public transportation

\section{b. Transportation to Reach Tourism Areas}

Transportation is an effort to provide a vehicle for anyone to be able to access the location. That is why in the analysis of transportation is very important [6]. Transportation that can be used to reach this tourist area is limited. Only motorcycles and small cars can access the location. Moreover, before able to reach the tourism area, tourist should travel by ships, and if the condition of low tide, tourists has to walk to the ship.

\section{c. Visitor Target}

A tourism development effort must take carefully and comprehensive. The development of tourism also does not only rely on nature, but should be carefully developed. Some aspects that must be considered was to know the type / characteristics of tourists, from what country they come from, age, hobbies, and in what season they travel [7].

Tourists visiting the exotic mengare mangrove tourism area are dominated by local people. From the manager also stated that the target of visitors is the local community, especially those who want to get education about the estuary and mangrove ecosystems. As well as historical sites that is in the area.

\section{d. Promotion}

Promotion is a marketing activity carried out in order to communicate with the market, using the composition of the promotional mix. The promotion mix is a combined flow of information. This is different from marketing communication which aims to satisfy all parties. All parties involved in the marketing communication process use the same method of listening, reacting and speaking until a satisfying exchange relationship is created [8].

The manager has made instagram pages (@exoticmengare_official) to inform the public about the exotic mengare mangrove tourism area. It is just that what has been tried is still not optimal because most tourists visit the area by word of mouth.

\subsubsection{Other related resource components (other than tourism)}

Activities are what tourists do in tourist destinations. Diverse activities for tourists can increase tourist spending. Furthermore, business activities can be carried out by local residents. Business activities can be in the form of sales of services or services or the sale of goods to tourists [4].

Exotic mengare mangrove tourism area not only provides a place for tourist facilities. It also provides a place for education, training and camping facilities. The results of the questionnaire that obtained stated that other resources related components that can be done in the exotic mangrove tourism area can be seen in Table 5 .

Table 5. ECOS Assessment of Other Related Resource Components

\begin{tabular}{lcccc}
\hline \multicolumn{1}{c}{ Subject Assessment } & ES & IM & EG & Total \\
\hline Linkage to other activities & 4 & 26 & 0 & 30 \\
Total & 4 & 26 & 0 & \\
\hline Indicator & \multicolumn{5}{c}{ Intermediate } \\
\hline
\end{tabular}


Other resource components related to tourist areas were classified as Intermediate. Whereas the information obtained from respondents stated that in the exotic mangrove tourism area, are not only be used for tourism, but can also be used for other activities such as fishing, camping and also a place to study. The activities that can be done are still very dependent on natural conditions and the scope of activities is still very small so that it is still classified as an intermediate indicator.

\subsubsection{Attraction Components}

Attractions can also be realized in the form of rides or even the main things offered in a tourist attraction [4]. The exotic mengare mangrove tourism area offers a variety of attractions including rivers, beaches, tropical forests, mangroves, heritage, culinary, fishing and nature games. Based on the results of the questionnaire that has been obtained from respondents regarding access components the results obtained are as in Table 6.

Table 6. Ecos Ratings on the Attraction Component

\begin{tabular}{llccc}
\hline \multicolumn{1}{c}{ Subject Assessment } & ES & IM & EG & Total \\
\hline The naturalness of the recreational vehicle & 18 & 12 & 0 & 30 \\
Total & 18 & 12 & 0 & \\
\hline Indicator & Eco Specialist & &
\end{tabular}

The attraction component in the tourist area is classified as Eco Specialist. Where respondents stated that the attractions offered are still oriented to nature.

Every tourist is charged a fee of Rp. 35,000 including the cost of boat transfer from the pier to the ticket window. Tourists can explore the entire tourist area starting from 07.00 to 17.00 without any additional cost. However, if tourists come and register for the Student Leadership Basic Training activities, they can set up tents and spend the night. The fee also includes compensation costs of an accident while in the tourist area.

\subsubsection{Infrastructure Components}

Tourism comprehensively is an industry which is engaged in promoting services from various measurable and immeasurable elements. Measured elements include all forms of transportation, roads, water, health services - accommodation, food and beverages, tourists and souvenirs, as well as services related to tourist activities, such as banks, security and comfort insurance. Meanwhile immeasurable elements include rest activities, adventure culture, and new and different experiences [9].

Infrastructure in this case becomes a matter of concern for developing the mengare tourism area. Based on the results of the questionnaire that has been obtained can be seen in Table 7 .

Table 7. ECOS Assessment in Infrastructure Components

\begin{tabular}{lcccc}
\hline \multicolumn{1}{c}{ Subject Assessment } & ES & IM & EG & Total \\
\hline Facilities and infrastructure & 12 & 18 & 0 & 30 \\
Travel Completeness & 0 & 30 & 0 & 30 \\
Addition and development of facilities & 4 & 26 & 0 & 30 \\
\hline Total & 16 & 74 & 0 & \\
\hline
\end{tabular}




\begin{tabular}{ll}
\hline Indicator & Intermediate \\
\hline
\end{tabular}

The Infrastructure component of the tourist area is classified as Intermediate. This component is assessed from three assessment subjects namely facilities and infrastructure, tourism equipment, and the addition and development of facilities.

\section{a. Tourism Infrastructure and Completeness}

Facilities and infrastructure is one important factor that greatly supports the growth of the tourism industry and must exist in to create tourist satisfaction and also it can be one of the supports for tourists. If the facilities and infrastructure are not well developed, it will reduce the interest of tourists to visit [4].

The management has provided the facilities and infrastructure in the exotic with gazebos, bins, chairs and toilets. However, there is also no installation of water and electricity to support tourism activities.

b. Addition and Development of Facilities

The manager of the exotic mengare stated that tourist area continues to be strived for additional facilities as this area is still new so many facilities that must be provided. The latest additiobal facilities is the addition of trash bins so visitors do not leave trash while traveling. Financial problem is also the main obstacle today for addition of tourist support facilities.

\subsubsection{Components of Ability and Knowledge Level}

This component relates to individuals who want to reach the exotic mengare mangrove tourism area, from the authorities and managers and the community. Based on the results of the questionnaire, the results can be seen in Table 8 .

Table 8. ECOS Assessment on the Capabilities and Knowledge Components

\begin{tabular}{lcccc}
\hline \multicolumn{1}{c}{ Subject Assessment } & ES & IM & EG & Total \\
\hline Visitor skills and knowledge & 0 & 18 & 12 & 30 \\
Total & 0 & 18 & 12 & \\
\hline Indicator & Intermediate \\
\hline
\end{tabular}

Components of the level of ability and knowledge in the tourist area are classified as Intermediate. This component is related to the skills that must be present in each individual tourist to reach a place. In the existing tourist area of the plains in the form of embankment ponds and also mangrove and tropical forests. Tourists must walk to explore the entire tourist area from Ayang-ayang Beach to Lode Wijk Fortress.

\subsubsection{Components of Social Interaction}

Social interaction is a phenomenon of the relationship between individuals, where several individuals can influence each other, in the sense is an interaction. Social interaction is one way for individuals to behave towards other individuals and maintain social interaction with other individuals [10]. 
Social interactions that occur within the exotic mengare mangrove tourism area involve three elements, namely tourists, the surrounding community and also the management of the area. From the results of the questionnaire obtained results can be seen in Table 9 .

Table 9. ECOS Assessment on the Components of Social Interaction

\begin{tabular}{lcccc}
\hline \multicolumn{1}{c}{ Subject Assessment } & ES & IM & EG & Total \\
\hline Relations with local community & 22 & 8 & 0 & 30 \\
Total & 22 & 8 & 0 & \\
\hline Indicator & Eco Specialist & & \\
\hline
\end{tabular}

The component of social interaction in the tourist area is classified as Eco specialist. Interactions involving local residents from the Exotic Mengare mangrove tourism area were minimal. Not many local residents were involved in tourism activities carried out by the management of Exotic Mengare. For almost two years the operation, the management only consist of 5 people and 5 food seller in the tourist area with two units of ship operated. The one who controlled are the work team itself, especially those who work in the menagement. This happens due to the lack of synergy between management, local communities and local government officials.

\subsubsection{Components of Visitor Impact}

According to [11] the impact of tourism is the area of study that receives the most attention in the literature, especially the impact on local communities. Although tourism gathers various aspects of community such as politics, security, and so on, the impact of tourism on the community and tourist destination areas that receive a lot of reviews is the economic, socio-cultural, and environmental impacts

Tourism activities in the exotic mengare certainly have an impact on the environment. Based on the results of the questionnaire can be seen in Table 10 .

Table 10. ECOS Assessment on the Visitor Impact Component

\begin{tabular}{lccccc}
\hline & \multicolumn{1}{c}{ Subject Assessment } & ES & IM & EG & Total \\
\hline \multicolumn{2}{c}{ Level of supervision and degree of impact } & 2 & 28 & 0 & 30 \\
Total & 2 & 28 & 0 & 30 \\
\hline Indicator & \multicolumn{4}{c}{ Intermediate }
\end{tabular}

The component of the impact of visitors on the tourist area is classified as Intermediate. The one impact caused by visitors is usually left the garbage inside the tourist area. However, the management has anticipated by increase the number of trash bins.

The impact of visitors on social interactions is also very small. Where there is almost no interaction from visitors to the surrounding community except management. There is no economical impact on the community.

\subsection{Recreation Zone Index (RZI)}

Determination of the indicators owned by the exotic mengare tourism area of the seven predetermined components can be calculated using the RZI Formula. Calculations are carried out using the value of each indicator in each component. The indicators of the components have their respective values, if the component has an Eco Specialist indicator then it has a 
value of "2", if the Intermediate has a value of "1" and if the Eco Generalist has a value: 0 ", the results of each component can be seen in Table 11.

Table 11. Value of ECOS components

\begin{tabular}{clll}
\hline No & Component & Indicator & Score \\
\hline 1 & Access & Intermediate & 1 \\
2 & Other related resources & Intermediate & 1 \\
3 & Attractions & Eco Specialist & 2 \\
4 & Infrastructure & Intermediate & 1 \\
5 & Social interactions & Eco Specialist & 2 \\
6 & Level of ability and knowledge & Intermediate & 1 \\
7 & Impact of visitors & Intermediate & 1 \\
\hline \multicolumn{2}{r}{} & & 9 \\
\hline
\end{tabular}

From these results the RZI can be calculated using the following formula:

$$
\begin{aligned}
& R Z I=\sum\left(\frac{N i}{N \max }\right) \times 100 \% \\
& R Z I=\sum\left(\frac{9}{14}\right) \times 100 \%=64,28 \%
\end{aligned}
$$

From these results it can be seen that the value of RZI is at $64.28 \%$. The figure shows that the indicator of the exotic mengare was intermediate. With these conditions, there are many efforts to develop the tourist area to maximize the existing potential.

Tourism that has an intermediate indicator has seen a pattern of development. This is indicated by the growing number of visitors. Public expectations of the tourist area have improved and are aware that this tourist area already has an attraction that is worth visiting [2].

\subsection{Development Strategies of tourist areas based on ECOS components}

The conditions and indicators of the exotic mengare determined as a reference in determining future development strategies. Also, by paying attention to existing limiting factors. In ECOS the existing development strategy is grouped by components within ECOS itself.

The development strategy offered was based on regional indicators which are in the intermediate category and the direction of development strategies that must be carried out determined by prioritizing environmental interests because the area also has an ecological role. But still consider the social economic aspects of the community around the tourist area.

\section{a) Access Component Development Strategy}

The indicator of the access component in the exotic mengare is in the intermediate spectrum. Access in this case relates to how visitors can get to the place. From the findings obtained, that there is enough access to accommodate visitors to arrive and explore the tourist area. The availability of several facilities such as transports and promotional media that are easy to access, but not optimal to accommodate visitors wants. Some of the findings obtained regarding the lack of access components were:

- Media promotion is not yet maximal so visitors tend to receive information about the area from mouth to mouth. 
- The several strategies for developing tourist areas in the access component that can be done by the manager were:

- Maximizing the promotion through social media with more interactive and informative.

- Socializing Exotic Mengare directly for the people who do not use social media.

b) Strategies for Developing Other Related Component Resources

Activities that can be done in the exotic mengare are not only limited to tourism activities. These activities are still dependent on the carrying capacity of the environment and weather conditions so this component in the Intermediate spectrum. However, there must be development that done by the management, especially with the addition of non-tourism facilities. There are several findings related to deficiencies, namely:

- Lack of facilities to accommodate non-tourism activities.

- The absence of booklets related to the exotic mangare So the development strategies that can be carried out include:

- $\quad$ Provision of tent facilities for the purposes of LDKS training and so on.

- $\quad$ Making booklets related to the education of mangrove areas.

c) Attraction Component Development Strategy

Attraction is the main thing of a tourist area. Attractions that operates in exotic mengare is limited to the existing ecosystem in the region. There is lack of technology to make this component in the eco specialist spectrum. Thus more attention must be paid to the development of attractions. There are several findings related to the lack of attraction components, namely:

- There is little discrepancy in the facilities obtained by tourists from what is listed on the entrance ticket such as river attractions, culinary, fishing, and nature games.

- $\quad$ Less diverse food tenants.

Strategies that can be applied in efforts to develop tourism in the attractions component include:

- Increasing the number of kayaking so that many tourists can experience the experience of kayaking.

- Add attributes or photo spots to attract tourists.

- Facilitating tourists who have a hobby of fishing.

- Additional local culinary stand in Mengare Village.

d) Infrastructure Component Development Strategy

Infrastructure is an aspect that is directly related to the comfort of tourists. The good and bad of a tourist area can be judged by the condition of its infrastructure. The condition of the infrastructure provided in the exotic mengare has been able to accommodate tourists who visit. Some of the infrastructure that is provided by the management include the pier, gazebo, toilets, seating, and canteen. But all of them have not function optimally. So there are several strategies that can be used to develop infrastructure components, including:

- Revitalizing toilets around the fort and adding toilets in the coastal area. Because tourists who are on the beach have to walk far to go to the toilet.

- Procurement of clean water installations. At present the clean water supplied is still manually taken from the village so the amount is limited.

- The addition of counters on the pier. 
e) Capability Strategy and Knowledge Component Development

In order to be able to explore the entire tourist area, it does not require special abilities for visitors however, tourist area is quite extensive with many attractions that are far apart. This makes the spectrum of these components in the intermediate indicator.

f) Development strategies for social interaction

The establishment of tourism area should receive attention from the local community because the activities of tourism will intersect with the surrounding community. Unfortunately in this region the social interactions that exist between management, local communities and visitors are minimal. This can be seen at least the number of local people involved from existing tourism activities so that this component is included in the Eco Specialist spectrum.

This of course requires a strategy to change the conditions that are happening. The strategies to develop this are:

- Management collaborate in the development of tourist areas with local government to attract public sympathy

- Make SOPs from management to be more interactive with visitors

g) Development Strategy for Visitor Impact Components

The activities of visitors who travel in the area is still have an impact both in terms of ecological and economic. However the impact caused is narrow scope. On the ecological impact of visitors, the volume of waste has increased in relatively small amount, so that supervision by the manager is easy. While in terms of the economy is also in low impact, especially on the surrounding community even almost none. This makes this component in the Eco Specialist spectrum.

From the explanation above, it can be determined several strategies that can be used as development efforts to improve this component, including:

- The management opens the opportunity for the local community to join the exotic mengare work team

- Spread more information related to food tenants within the area so that people can know and want to sell.

- Involving the local community exclude the management in the aspect of service to visitors

- Limiting the number of visits every day to anticipate if there is an addition in the number of visitors

\section{Conclusions}

From the description of related components and indicators that form the basis of development strategies in the exotic mengare tourism area, it can be concluded that:

a) Exotic Mengare mangrove tourism area condition that has been analyzed with ECOS approach resulted in 5 indicators in Intermediate and 2 indicators in eco-specialist. This condition showed that the exotic mengare mangrove tourism area is suitable for ecotourism.

b) From the calculation of RZI which determined by scoring of each component has a value of $64.28 \%$ which means Intermediate, so the development can be carried out according to the conditions of each component by prioritizing the ecological and socio-economic sustainability of the surrounding community. 
c) Development strategies that can be carried out on the exotic mengare mangrove tourism area can be implemented in accordance to maximize the promotion, provide facilities outside the tourist area, adding some tourism attractions, develop infrastuructre and make SOP's for management and limiting the visitors.

\section{References}

[1] B. J. Timur, Kabupaten Gresik. Gresik: Pemprov Jatim, 2013.

[2] S. W. Boyd and R. W. Butler, "Managing ecotourism: an opportunity spectrum approach," Tour. Manag., vol. 17, pp. 557-566, 1996.

[3] M. K. Wardhani, "Mangrove Ecotourism Opportunity Spectrum at South Coast of Bangkalan Province of East Java," 2013.

[4] I. H. Way, C. E. V Wuisang, and S. Supardjo, "Analisis Kebutuhan Prasarana dan Sarana Pariwisata di Danau Uter Kecamatan Aitinyo Kabupaten Maybrat Propinsis Papua Barat," SPASIAL, vol. 3, no. 3, pp. 27-37, 2016.

[5] H. C. Murti and S. Sujali, "Persepsi Wisatawan Terhadap Pengembangan Obyek Wisata Batang Dolphin Center," J. Bumi Indones., vol. 2, no. 2, 2013.

[6] N. Budiartha, "Peranan Transportasi dalam Pariwisata, Studi Kasus: Pemilihan Daerah Tujuan Wisata (Dtw/Destinasi) oleh Wisatawan di Bali,” J. Ilm. Tek. Sipil, vol. 15, no. 2, pp. 195-204, 2011.

[7] N. Nurhidayah and M. Musadad, "Karakteristik Pengunjung Pada Objek Wisata Danau Cipogas Kabupaten Rokan Hulu." Riau University, 2017.

[8] R. Tasruddin, "Strategi Promosi Periklanan yang Efektif," J. Al-Khitabah, vol. 2, no. 1, 2015.

[9] E. F. Rozy and A. Y. Koswara, "Karakteristik Infrastruktur Pendukung Wisata Pantai Sanggar Kabupaten Tulungagung," J. Tek. ITS, vol. 6, no. 2, pp. A712-A716, 2017.

[10] V. N. Fatnar and C. Anam, "Kemampuan interaksi sosial antara remaja yang tinggal di pondok pesantren dengan yang tinggal bersama keluarga," Empathy, vol. 2, no. 2, pp. 71-75, 2014.

[11] I. K. Suwena, I. G. N. Widyatmaja, and M. J. Atmaja, Pengetahuan Dasar Ilmu Pariwisata. Udayana University Press, 2010. 